\title{
SOUTHERN POLICY OF THE NEO-ASSYRIAN STATE AND THE ELAMITE-BABYLONIAN ALLIANCE
}

\author{
Okay PEKŞEN*
}

\begin{abstract}
$\ddot{O} z$
Yeni Asur Devleti’nin Güney Politikası ve Elam-Babil İttifakı

Asur Devleti MÖ I. binyılın başlarından itibaren yeniden güç kazanmaya başlaması ve emperyal bir hüviyete bürünmesiyle uzak bölgelere askeri seferler yapabilme kabiliyeti kazanmıştır. Asur Devleti'nin bu faaliyetleri, komşu bölgelerdeki devletleri tedirgin etmiştir. Yeni Asur Dönemi olarak adlandırılan bu süreçte Asur orduları, Mısır'dan Elam'a, Babil'den Anadolu içlerine kadar uzanan geniş bir coğrafyada faaliyet göstermiştir. Bu dönemde, Asurluların hâkimiyetleri altında tutmak istedikleri en önemli bölge Babil ülkesidir. Bölgenin sahip olduğu ekonomik potansiyel, Asurluların bu bölge ile yakından ilgilenmelerine neden olmuştur. Söz konusu bölge Sumer ülkesinin doğusunda bulunan Yeni-Elamlıların da hâkimiyet kurmak istedikleri bir coğrafyaydı. Babil ülkesinin Asur kontrolüne girmesini istemeyen Yeni-Elamlılar, Asur karşıtı tüm isyan girişimlerini desteklemiştir. Yeni-Elamlıların bu politikadaki temel amaçlarından bir diğeri de Asurlular ile sınırdaş olmak istememeleridir. Asurlular ise bölgeye hâkim olabilmek amaciyla hem Babil ülkesine hem de Elam topraklarına pek çok askeri sefer düzenlemelerinin yanı sıra diplomatik ilişkilerde de bulunmuşlardır. Çalışmamızın konusunu oluşturan bu mücadele ve diplomatik ilişkilerin incelenmesinde Asur ve Babil çivi yazılı metinleri ile modern literatür kullanılmıştır. Bazı bölümlerde çivi yazılı metindeki bilgilerden doğrudan, bazı bölümlerde ise dolaylı olarak faydalanılmıştır. Asur, Elam ve Babil üçgenindeki eksenindeki siyasi, askeri, kısmen de ekonomik yönlerinin ele alınacağı bu çalışmada elde edilen bilgilerden hareketle, MÖ I. binyılda Asur Devleti'nin hegemonik yayılmasına karşı Elam ve Babil ülkeleri tarafından yürütülen faaliyetler ve Asurluların bu faaliyetlere karşılık aldığı tedbirler ele alınmış ve değerlendirilmiştir.
\end{abstract}

Anahtar Kelimeler: Asurlular, Hegemonya, Babil Sorunu, Yeni-Elamlılar, Kaldeliler.

\footnotetext{
* Assoc. Prof., Ondokuz Mayis University, Faculty of Art and Sciences, Department of History, Samsun/Turkey.

E-mail: okaypeksen@gmail.com; okay.peksen@omu.edu.tr. ORCID: 0000-0003-4841-5427

(Makale Gönderim Tarihi: 30.04.2021 - Makale Kabul Tarihi: 16.08.2021)
} 


\title{
Okay PEKŞEN
}

\begin{abstract}
Because the Assyrian state started to strengthen in the early first millennium BC by acquiring an imperial identity, it gained the capacity to launch military campaigns across remote regions, which, not surprisingly, disturbed and threatened the neighboring states. In this period, which is called the Neo-Assyrian period, Assyrian armies prevailed in a vast geographical region, extending from Egypt to Elam and reaching into even Babylonia and Anatolia. The most important region which Assyrians aimed to reign in the given period was Babylonia. They showed a great interest in the region due to its high economic potential. However, Elam, which was located in the eastern region of Sumerians, was also interested in the same region. Because they aimed to prevent a potential Assyrian hegemony over Babylonia, Neo-Elamites usually supported all anti-Assyrian rebellions. Another reason why Neo-Elamites adopted this policy lied in the fact that they saw it as necessary to prevent Assyrians from being a bordering state. On the other hand, Assyrians organized various military campaigns against both Babylon and Elam in order to control the region as well as conducting diplomatic relations. Therefore, the present study focuses on the struggle among these three states and their diplomatic relations by relying on Assyrian and Babylonian cuneiform texts and modern literature and refers to these cuneiform texts directly and indirectly in different parts of the study. In this way, the present study deals with conflict among Assyria, Elam and Babylon from a political, military and, to a certain extent, economic perspective and analyzes Neo-Elamite and Babylonian policies against hegemonic expansion of the Assyrian state in the first millennium $\mathrm{BC}$ and various measures taken by the Assyrian state against this alliance.
\end{abstract}

Keywords: Assyrians, Hegemony, Babylonian Problem, Neo-Elamites, Chaldeans.

\section{Introduction}

Elam was first used as a name for a geographical region in cuneiform texts to define the territory in the eastern region of the Sumerian land following the emergence of first city-states in Mesopotamia ${ }^{1}$. Elamite territory was mentioned as elamtu / elammatum and KURElamtu in Akkadian and Assyrian cuneiform texts. Etymological studies indicate that these words were derived from Akkadian words "elû (higher, upper)" and "mātu (country) ${ }^{2}$. It seems that the most important reason why this territory, which is located in the eastern part of Persian Gulf in today's Iran, was called a high country was the mountainous geography of the region, with Zagros Mountains being the highest mountain range.

Elamite city-states (Middle Elamite III period) were among the greatest rivals of the Assyrian state in the period which modern historians call Middle Assyrian Period. In addition, Assyrians attached much importance to the region, as it was endowed with a high commercial and agricultural potential ${ }^{3}$. There is no doubt that Elam played an important role in the process which ended with the fall of the Middle Assyrian state. The Assyrian state started to decline following the death of Tiglath-Pileser I (1114-1076 $\mathrm{BC})$ and was also affected negatively when the Elamites started to control economic sources in Southern Mesopotamia ${ }^{4}$.

\footnotetext{
${ }^{1}$ King 1910, p. vi; Memiş, 2020, p. 6.

2 Álvarez-Mon 2012, p. 740; Waters 1997, p. 18; Waters 2013, p. 478.

${ }^{3}$ Toptaş 2021, p. 112.

${ }^{4}$ Memiş 2020, p. 223.
} 
The Assyrian Kingdom started to reclaim its military and political power in the $9^{\text {th }}$ century BC and became the greatest political power in the Near East for nearly three hundred years (934-610 BC). This period is called the Neo-Assyrian Period by modern scholars $^{5}$. After Assyrians had managed to reign over a large territory in the ancient Near Eastern geography during the Neo-Assyrian Period, the Elamite state was first mentioned in an Neo-Assyrian cuneiform text during the reign of Shamshi-Adad V (822 $-811 \mathrm{BC}$ ). The text in question informs us that the Assyrian king launched a military campaign in a territory called ${ }^{\mathrm{KUR}}$ Elamtum and fought against the Babylonian king, Marduk-balāțsu-iqbi (c. 819-813 BC), who maintained a hostile attitude towards Assyrians and allied with Elamites against them, resulting in a large amount of spoil of war for Assyrians ${ }^{6}$. A high number of prisoners and a large amount of spoil of war in this military campaign are narrated in the inscriptions of Shamshi-Adad V as follows:

"Marduk-balățu-iqbi, trusting in the mass of his army, mustered the lands Chaldaea, Elam, Namri, and Aram, with his multitudinous troops (and) moved forward to wage battle and strife against me. He drew up the battle line of his troops by the River Daban in front of the city DūrPapsukkal. I fought with him (and) defeated him. I slaughtered 5,000 of his hordes (and) captured 2,000alive. I took away from him 100 chariots, 200 cavalry, the pavilion, his royal tent, (and) his campbed."7

The Neo-Assyrian state, which was the most important military power in ancient Near East region, had a completely imperial identity. The largest borders of this state reached Elamites and Medes in the east, Tyre, Israel and Kingdom of Judah in the west, Arameans and Neo-Hittite city-states in northern Syria, Urartian Kingdom in the north, and Neo-Hittite city-states in the Anatolia and $\mathrm{Egypt}^{8}$. The conflict between Assyrians and Elamites was particularly visible when Assyrian kings sought to assert their control over Near Eastern geography. Assyrian or Babylonian cuneiform texts offer valuable information regarding these struggles and political atmosphere in Elam ${ }^{9}$.

\section{Neo-Elamite and Babylonian Problem in the Neo-Assyrian State}

The political weakness of the Assyrian state in the early $8^{\text {th }}$ century BC was ended by Tiglath-pileser III (744-727 BC). However, he needed to make certain efforts in order to eliminate these political problems during his reign, as Assyrian hegemony over the Babylonian territory tended to decline during the reign of Adad-nirari III (810783 BC). In this period, some Chaldean leaders were supported by Neo-Elamites to find their own independent dynasties and demolish Assyrian hegemony in the region ${ }^{10}$. This problem caused by Babylonians urged Assyrian kings to intervene militarily in the region many times. As a result of these political developments, the Assyrians were

\footnotetext{
${ }^{5}$ Kuhrt 2013, p. 123.

${ }^{6}$ Waters 2013, pp. 481-482.

${ }^{7}$ RIMA 3, A.0.103.1, iv 37-45.

${ }^{8}$ Köroğlu 2013, p. 142.

${ }^{9}$ Toptaş 2021, p. 113.

${ }^{10}$ Yiğit 2020, p. 195.
} 


\section{Okay PEKŞEN}

engaged in a war with allied Neo-Elamite and Chaldean forces to maintain their hegemony over a region with significant economic and political potential ${ }^{11}$, which is also clearly mentioned in cuneiform texts. These texts offer information about military campaigns launched by the Assyrian king, Tiglath-pileser III, to overcome some problems and, to some extent, exaggerate his victories ${ }^{12}$. It is not surprising that reformation movements of Tiglath-pileser III in the Assyrian army played a vital role in his military success, which enabled the army to gain power, extend its sphere of influence and organize military campaigns in remote regions ${ }^{13}$.

With the modernization of Assyrian army, Tiglath-pileser III became an even more powerful king and planned to make his hegemony felt over the Elamite territory due to its critical role in the Babylonian problem as well as its remarkable economic potential. In this respect, he launched various military campaigns against the NeoElamite state and conquered Hilimmu and Pillatu due to their strategic locations in controlling the Elamite territory. Following the Assyrian conquest of these cities, the Neo-Assyrians and the Neo-Elamites became neighboring states, giving the NeoElamites a sense of threat. During the reign of Tiglath-pileser III, however, Assyrian armies made no attempts to attack central parts of Elamite territory. The most intense battles between two states and great military campaigns against Elam took place during Sargonid dynasty $(722-626 \mathrm{BC})^{14}$.

The Assyrian state enjoyed its most powerful period during Sargonid dynasty in the $7^{\text {th }}$ century BC, when they controlled the whole Fertile Crescent and the Egyptian territory for a time. In addition, all strategic trade routes were controlled by Assyrians in this period. Nevertheless, Assyrian kings had to deal with various activities of antiAssyrian groups which took advantage of political instability during the reigns of Tiglath-pileser III and Shalmaneser V in various regions where Assyrians were dominant such as the Babylonian territory in the south and Elamite territory in the east $^{15}$. Babylonian throne was taken under control by Assyrian kings for a period between 728-722 BC. Following the death of Shalmaneser V in late 722 BC, the family inheritance of Assyrian throne came to a halt, and, finally, Sargon II became the new Assyrian king. Due to temporary problems and domestic turmoil among the Assyrian authorities during the first years of his reign, the Babylonian state declared its independence which would last for nearly twelve years ${ }^{16}$. Sargon II needed to address so many problems in this period that he fought against many different enemies, as can be found in Khorsabad (Dur-Sharrukin) texts and annals. Among these enemies are Urartians, Arameans and Neo-Hittite city-states, Medes and Mannaeans who lived in northeastern regions of today's Iran, Neo-Elamites in the southern regions of Assyrian state and Babylonians supported by the Neo-Elamites ${ }^{17}$.

\footnotetext{
${ }^{11}$ Kuhrt 2013, p. 154.

${ }^{12}$ Gökçek 2015, p. 160.

${ }^{13}$ Köroğlu 2013,p. 168.

${ }^{14}$ RINAP 1, no. 47, 13-14; RINAP 1, no. 51, 17.

${ }^{15}$ Kuhrt 2013, p. 123; Y1ldırım 2017, p. 94.

${ }^{16}$ Brinkman 1965, p. 161; Köroğlu 2013, p. 168.

${ }^{17}$ Gökçek 2015, pp. 166-167.
} 
The alliance between Neo-Elamites and Babylonians against Assyrians turned into a strong coalition after Marduk-apla-iddina $\mathrm{II}^{18}$ (721-710 BC), who was then the Chaldean king, had conquered Babylonia with the Neo-Elamites' support ${ }^{19}$. As a result of this alliance, the Neo-Elamite kings occasionally provided armed support and political asylum to Marduk-apla-iddina $\mathrm{II}^{20}$. Because Marduk-apla-iddina II declared Babylonian independence by taking advantage of change of throne in the Assyrian state, Sargon II launched his first military campaign against Babylon in order to punish Marduk-apla-iddina II in $720 \mathrm{BC}^{21}$. The main reason for this was undoubtedly Sargon II's desire to maintain Assyrian hegemony over Babylonian territory as a gate to the trade routes in the Persian Gulf. In addition to Babylonian independence, another reason for the military campaign was the fact that Marduk-apla-iddina II's conquest of the city of Uruk, which was an important trade center for commercial activities in the Persian Gulf, contributed to Assyrians' economic interests negatively ${ }^{22}$. Finally, leading figures of Babylon society also informed Sargon II about the mistreatment of Marduk-aplaiddina II, whom they called "a barbaric Bedouin", and asked the Assyrian king to defeat him. On the other hand, Neo-Elamite kings also aimed at establishing their authority in this region. Therefore, they openly supported Marduk-apla-iddina II to create a buffer zone between the western borders of Elam and the Assyrian state through a Babylonian king whom they could control easily. As a result, Neo-Assyrian and NeoElamite armies fought each other due to Marduk-apla-iddina II anti-Assyrian activities thanks to the Neo-Elamite king Ummanigash I's (Humban-nikash I) support. During this military campaign, near the city of $\mathrm{De}^{23}{ }^{23}$, Assyrian armies were defeated heavily by the Babylonian army supported by Neo-Elamites ${ }^{24}$. The reason underlying Sargon's attack on the city of Dēr was the strategic location of the city at a road connection between Babylonia and Susa. In addition, the city of Dēr also functioned as a buffer zone against any attacks that might come from Elam to Assyria, and a base for Assyrian campaigns against Babylonia ${ }^{25}$. Even though Assyrian annals which give information about this battle state that Sargon II was the victorious side, they contradict with Babylonian chronicles arguing that the Assyrian army was defeated ${ }^{26}$. Furthermore, exaggerated and impartial narrative style in Assyrian chronicles as well as the Babylonian king's control and hegemony over the region until $710 \mathrm{BC}$ suggest that the Assyrian army was defeated by the Babylonian army. The defeat of Assyrian army can also be attributed to their constant struggles with several different political powers in

${ }^{18}$ The king is referred to as Merodach-Baladan II in the Old Testament. For further information, see 2 Kings 20, 12; Isaiah 39, 1.

${ }^{19}$ Brinkman 1972, p. 279; Kuhrt 2013, p. 266; Yiğit 2020, p. 200; Toptaş 2021, p. 113.

${ }^{20}$ Brinkman 1965, p. 161; Köroğlu 2013, p. 168; Arnold 2004, p. 90.

${ }^{21}$ Galter 2007, p. 532; Elayi 2017, p. 171.

${ }^{22}$ Memiş 2020, p. 245.

${ }^{23}$ The city of Dêr is identified with the mound of Tell Aqar, about a kilometer northwest of the today's town of Badra. see Elayi 2017, p. 171.

${ }^{24}$ Waters 1997, p. 19; Kuhrt 2013, p. 156; Yiğit 2020, p. 200; Toptaş 2021, p. 114.

${ }^{25}$ Elayi 2017, pp. 171-172.

${ }^{26} \mathrm{ABC} 1, \mathrm{i} 33-35$. 


\section{Okay PEKŞEN}

different fronts such as Mediterranean city-states, Arameans and Urartians ${ }^{27}$. Mardukapla-iddina II mentions in his cuneiform texts that he won a great battle against the Assyrian army. However, when Babylonian chronicles which were written in a relatively impartial manner are analyzed, it can be inferred that Marduk-apla-iddina II was late to arrive on the battlefield and thus the victory was achieved by Elamite troops ${ }^{28}$. The battle is narrated in Babylonian chronicles as follows:

"The second year of Merodach-baladan (II): Humban-nikash (I), king of Elam, did battle against Sargon (II), king of Assyria, in the district of Dēr, effected an Assyrian retreat, (and) inflicted a major defeat upon them. Merodach-baladan (II) and his army, who had gone to the aid of the king of Elam, did not reach the battle (in time so) he (Merodach-baladan II) withdrew." 29

Despite all these political and military developments in the Babylonian territory, Sargon II was forced to abort his military campaigns again in southern regions for some time. This decision may have possibly resulted from his intention to eliminate domestic problems in the Assyrian territory and develop positive relations with Babylonians. Because Sargon II could not achieve his goals through military intervention, he planned to overcome problems on the southern borders of his state and signed a treaty with Marduk-apla-iddina II. The treaty was signed on an equal basis in $720 \mathrm{BC}$, which helped Sargon II gain some time in terms of solving various problems related to enemy states on the northern and northeastern borders of his state as well as domestic problems ${ }^{30}$. However, in $710 \mathrm{BC}$, as this treaty which was intended to help Assyrians gain some time was violated, Sargon II eventually directed his armies towards southern regions. In the next ten years following the treaty, the death of Ummanigash, who was then Elamite king and an ally of the Babylon, and the succession of Sutruk-Nahhunte II (717-699 BC), who was an inexperienced king and Ummanigash's niece, gave Sargon II the opportunity to launch another military campaign against the south ${ }^{31}$. At this time Surtuk-Nahhunte was named himself king of Anshan and Susa ${ }^{32}$. Following these developments, Sargon II made a strategic move when he started a military campaign against the Elam instead of the Babylon, as Sutruk-Nahhunte II, who were threatened by Assyrian attacks, retreated towards mountainous areas and thus deprived Marduk-aplaiddina II of the Neo-Elamite support. Due to his success in eliminating this alliance, Sargon II turned his face to the west and captured the city of Dur-Ladinnu. After a few military operations had been carried out, Assyrian hegemony was reestablished over the Babylonian territory, and leading figures of Babylonian society who invited Sargon II to the city welcomed him with a great joy. Marduk-apla-iddina II firstly fled towards southern regions and later sought political asylum from the Elamites following the fall

\footnotetext{
${ }^{27}$ Gökçek 2015, p. 168.

${ }^{28}$ Brinkman 1965, p. 161; Waters 1997, p. 19; Kuhrt 2013, p. 266.

${ }^{29}$ ABC 1, i 33-37.

${ }^{30}$ Cancik 2004, p. 92.

${ }^{31}$ Brinkman 1965, p. 163; Cancik 2004, p. 93.

32 Waters 1997, p. 25; Potts 1999, pp. 266-267.
} 
of Dur-Yakīn due to the constant attacks by the Assyrian troops. ${ }^{33}$ However, according to Assyrian annals, the Neo-Elamite king refused Marduk-apla-iddina II's asylum request due to his fear of the Assyrian army, as is mentioned in the following passage:

"[As a result, in the midst of his (own) palace] his own fear(s) fell upon him; he then went out (from Babylon) during the night together with [his] alli[es] (and) his battle [troop]s and set out for the land Yadburu, which is (part) of the land Ela[m]. He gave to [Š]utur-Nahūndi, the Elamite, [his royal] ut[ensils], a bed, a throne, a chair, a royal washbasin, (and) his neck ornament, as gifts from him in order to get [his] revenge (on me). (That) Elamite villain accepted his bribe, but [took fright at] my [weapon(s)]. He turned away and told him (Marduk-apla-iddina) that he would not come (to help him). (When) he (Marduk-apla-iddina II) heard the words of (the one who was to be) his avenger, he threw himself on the ground, ripped his [cloa]k, wielded (his) razor, and uttered cries of mourning. Together with his allies (and) [his] bat[tle] troops, that (man) moved away [from] the land Yadburu, entered int[o] the city Iqbi-Bēl, an[d] stayed (there) in [f]ear." 34

Thus, Sargon II managed to establish Assyrian hegemony over southern regions of the Persian Gulf for a certain period and controlled various trade routes extending from Iranian plateaus to Mesopotamian regions which were once lost due to the alliance between Elam and Babylon. However, such hegemony was still a temporary success for Assyrians because, in the following forty years, Assyrian kings had to make greater efforts to control the Babylonian and Elamite territory and adopt south-oriented state policies in the long run $^{35}$. Sargon II also launched military campaigns against Aramean tribes in the southern regions to consolidate Assyrian control and hegemony in this region $^{36}$.

After reestablishing Assyrian hegemony over Babylon by means of his victory in 710 BC, Sargon II started a number of city planning activities in this region. In addition, he attempted to declare himself as a legitimate king chosen by the divine power in order to maintain Assyrian existence permanent in Babylonia ${ }^{37}$. In this respect, he showed great respect for common religious beliefs in the city and joined in many sacrifice rituals dedicated to temples and gods ${ }^{38}$. However, despite Sargon II's all these efforts, after Assyrian hegemony began in 710 BC, Babylonian authorities were sometimes supported in their various rebellion attempts against Neo-Assyrian kings by the NeoElamites ${ }^{39}$. Although Babylonian influence weakened due to these developments, Elam still continued to pose a threat. In 708 BC, Daltâ, who was the king of the Ellipi

\footnotetext{
${ }^{33}$ Brinkman 1965, p. 163; Potts 2004, pp. 266-267; Cancik 2004, p. 93; Gökçek 2015, pp. 168169; Memiş 2020, p. 246.

${ }^{34}$ RINAP 2, no. $1,365-370$.

${ }^{35}$ Kuhrt 2013, p. 238.

${ }^{36}$ Waters 1997, pp. 30-32; Yiğit 2020, p. 200.

${ }^{37}$ Kuhrt 2013, pp. 267-269.

${ }^{38}$ Köroğlu 2013, p. 170.

${ }^{39}$ Gökçek 2015, p. 177.
} 


\section{Okay PEKŞEN}

Kingdom in the Zagros region, died in a fight for the throne which broke out between his two sons, i.e. Nibê and Ispabāra. Nibê sought help from Surtuk-Nahhunte and Ispabâra Sargon. According to the Assyrian kingdom annals of the Sargon period, Nibê and his Elamite supporters initially retreated towards the mountains and took control of the Marubištu fortress. However, Sargon's troops defeated Nibê and his supporters and managed to recapture Marubištu. This put Ellipi Kingdom under direct Assyrian influence, which was also the felt intensely in the Elamite territory ${ }^{40}$. When Sargon II died during a battle against enemies ${ }^{41}$ in Tabal in 705 BC, his son Sennacherib (705-680 BC) became his successor, which marked the beginning of a new era in the struggle between Assyria and Elam ${ }^{42}$.

The Babylonian problem emerged again in the first years of Sennacherib's reign. Assyrian chronicles written between 709-703 BC do not give any information regarding the fate of Marduk-apla-iddina II who stayed in the city of Iqbi-bēl following his defeat by Sargon II in $710 \mathrm{BC}^{43}$. According to these cuneiform texts, in $703 \mathrm{BC}$, some independent city-states on the Eastern Mediterranean coast and some vassal kingdoms in Palestine and Syria tried to take advantage of political instability following Sennacherib's succession to the throne and were supported by Egypt to start rebellions. Encouraged by these political events, Marduk-apla-iddina II too tried to draw Assyrian king's attention to western regions and supported these rebellions with the support of Elamite state to recapture Babylon and cause social turmoil in Babylon ${ }^{44}$. Marduk-zākiršumi II, referred to in the Assyrian cuneiform texts as "son of Arad" 45, led a rebellion in Babylon in $705 \mathrm{BC}$ and ascended to the throne. However, according to cuneiform texts, his reign lasted only one month because Marduk-apla-iddina II overthrew and dethroned Marduk-zākir-šumi. Similarly, Marduk-apla-iddina II could stay on the Babylonian throne only for nine months ${ }^{46}$. After Marduk-apla-iddina II had controlled Babylon with the support of the Neo-Elamite king Kudur-Nahundu, Sennacherib launched a series of military campaigns against Babylon in $702 \mathrm{BC}$, resulting in the reestablishment of Assyrian hegemony in the city and forcing Marduk-apla-iddina II to flee towards Elam ${ }^{47}$. During these campaigns, Sennacherib conquered numerous cities and settlements and ostracized 208.000 people towards central parts of Assyrian territory. Marduk-apla-iddina II's son was also among the captives. Spoils of war that Assyrians captured during these military campaigns are mentioned in some cuneiform texts as follows:

“...I returned safely to Assyria with 208,000 substantial captive, 7200

\footnotetext{
${ }^{40}$ Waters 1997, pp. 32-33; Potts 2004, p. 267; Medvedskaya 1999, pp. 53-54.

${ }^{41}$ Many modern scholars associate the enemy Sargon fought with the Cimmerians, see Tadmor 1958, p. 97; Hawkins 2008, pp. 420-423.

${ }^{42}$ Potts 2004, p. 267; Gökçek 2015, p. 177.

${ }^{43}$ Brinkman 1965, p. 164.

${ }^{44}$ Waters 1997, pp. 34-35; Waters 2011, pp. 286-287; Gökçek 2015, p. 180.

${ }^{45}$ RINAP 3/1, p. 23.

${ }^{46}$ Brinkman 1965, p. 164; Brinkman 1973, p. 91.

${ }^{47}$ Olmstead 1922, p. 74-75; Eph'al 1974, p. 110; Cancik 2004, p. 101.
} 
horses (and) mules, 11,073 donkeys, 5,230 camels, 80,050 oxen, (and) 800,100 sheep and goats. This is apart from the people, donkeys, camels, oxen, and sheep and goats that all of my troops had carried away and appropriated for themselves..."48

In the first few years following the conquest, Sennacherib asked Bel-ibni to become the Babylonian king, and directed his military campaign towards Syria and Palestine in order to quench rebellions in the western territory of his empire. However, new rebellions occurred in Babylon during these campaigns, which caused Sennacherib to intervene in the region once again. As a result, Bel-ibni's control over Babylon lasted for only three years ${ }^{49}$. After having controlled Babylon with a quick military intervention, Sennacherib enthroned his son, Aššur-nadin-šumi (699-694 BC), the crown prince, in order to preserve Assyrian hegemony over Babylon. Along with these developments in Babylon, the death of Marduk-apla-iddina II also contributed to Sennacherib's political power. Nevertheless, the source of the problem for Assyrian kings did not change, as the Elamites did not refrain from encouraging regional kingdoms to start rebellions against Assyrians in order to weaken Assyrian hegemony over Babylon $^{50}$. To achieve this goal, they formed various alliances with Babylonian and Chaldean tribes to secure the western borders of Elam. In order to offer a permanent solution to this problem, Sennacherib launched a military campaign directly against the Neo-Elamite state by attacking through sea routes $(696 \mathrm{BC})^{51}$. This tactic was quite contrary to the usual Assyrian military campaigns and thus required a long time for preparation. Syrian ship building masters were brought to the city of Nineveh to build ships for the military campaign and establish a large fleet for the Assyrian navy. After the ships had been built in the city of Nineveh, they were first taken to the city of Opis, which is located on the Tigris coast near today's Baghdad, and transferred to Euphrates by seamen through land routes for nearly 50 kilometers, while Assyrian troops continued proceeding towards Elam. Meanwhile, Hallušu-Inšušinak I, the Neo-Elamite king, retaliated this tactic by attacking the city of Sippar ${ }^{52}$. In 694 BC, anti-Assyrian groups in Babylon held Aššur-nadin-šumi, who was Sennacherib's son, captive in the city of Sippar and turned him over to the Elamites. As a result of these developments, the Elamite king appointed Nergal-ušezib (692-689 BC) to the Babylonian throne. Although there is limited information regarding the fate of Aššur-nadin-šumi, it can be stated that the Assyrian prince was possibly killed by Neo-Elamites ${ }^{53}$.

When Sennacherib learned his son's death due to a rebellion in Babylon, he attacked Elam and Babylon with a great army. Nergal-ušezib, who was also supported

\footnotetext{
${ }^{48}$ RINAP 3/1, n.1, 60.

${ }^{49}$ Brinkman 1973, p. 91; Zaia 2019, p. 250.

${ }^{50}$ ABC 1, ii 26-31; Waters 1997, pp. 36-37; Brinkman 2008, p. 35; Cancik 2004, p. 101; Yiğit 2020, pp. 203-204.

${ }^{51}$ Hansman 1978, p. 53; Potts 1997, p. 36.

${ }^{52}$ Gökçek 2015, pp. 181-182.

${ }^{53}$ Parpola 1972, p. 22-23; Brinkman 1972, p. 279; Brinkman 1973, p. 92; Brinkman 2008, p. 36; RINAP 3/1, p. 13; Ay Arçın 2020, p. 279.
} 


\section{Okay PEKŞEN}

by Neo-Elamites, was sitting on the Babylonian throne at the time. However, he was dethroned during Sennacherib's military campaign, held captive and taken to Assyria. The new heir to the Babylonian throne was Mušēzib-Marduk, who was himself a Chaldean ${ }^{54}$. After he was informed about the Assyrian king's military campaign against Babylon, Mušēzib-Marduk sent golden and silver treasures in Esagila Temple of Babylon to Umman-menanu (692-689 BC), the new Elamite king and son of HallušuInšušinak, to receive his support ${ }^{55}$. In addition, he also sent some gifts to Chaldean and Aramean tribes as well various other tribes around Zagros to receive their support and create a line of defense against Sennacherib. Neo-Elamite troops also took their part in the alliance against Assyrian armies. As a result, in $691 \mathrm{BC}$, an intense battle took place when two armies fought in Halulê near the city of today's Samarra on the Tigris coast, resulting in Sennacherib's victory and the death of the commander of Neo-Elamite troops $^{56}$. In these inscription, Sennacherib mentions this military campaign organized under difficult conditions against a large coalition as follows:

"...At the shore of the roiling sea — which was unsuitable and very difficult for (ships) to dock, horses to climb, and men to set foot on - the inhabitants of Chaldea [li]ving in the cities Nagitu (and) Nagìtu-di' bina, the people of the lands Hilmu, Pillatu, and Hupapanu saw the boats of my warriors and they gathered together archers, wagons, horses, (and) mules, a force [without] number. Before their (my warriors') arrival, while drawing up in battleline at the Ulāya River, a river with good shores, (and) holding my troops (landing place on) the high ground, they (the Chaldeans and Elamites) sharpened their weapons.

My warriors reached the quay of the harbor (and) like locusts they swarmed out of the boats onto the shore against them and defeated them. They conquered the cities Nagitu, Nagìtu-di'bina, Hilmu, Pillatu, and Hupapanu, cities of the king of the land Elam. They carried off their garrisons, the population of Chaldea, the gods of all of the land Bìt-Yakinn, [together with] their property, and the people of (the) Elamite (king), wagons, [horses], mules, (and) donkeys.

They loaded (them) onto [their] boat[s] and brought (them) to this side (of the sea), to the city Bāb-salimeti, b[efore me]. They destroyed, devastated, (and) burned with fire those cities. They poured out deathly silence over the wide land of Elam..." 57

Sennacherib, who caused great devastation in Elam and captured Babylon in 689 BC, also defeated Mušēzib-Marduk, who was then the king, and held his family captive. In addition, he also ordered his troops in Babylon to plunder the city and its many temples in order to take his son's revenge, destroyed some statues of god in the city and,

\footnotetext{
${ }^{54}$ Potts 1999, pp. 269-271; Brinkman 2008, p. 37; Ay Arçın 2020, p. 279; Yiğit 220, p. 156.

55 Brinkman 1965, p. 166; Waters 1997: p. 55; Akyüz and Toptaş 2020, p. 221.

${ }^{56}$ Brinkman 1973, p. 93; Waters 2011, p. 287; Gökçek 2015, pp. 182-183; Oates 2015, pp. 125126.

${ }^{57}$ RINAP 3/2, no: 46, 81b-99b.
} 
finally, took the statue of Marduk, who was the patron god of Babylon, to Assyria. He also changed Tigris river bed to divert it through destroyed walls of the city, which eventually turned Babylon into ruins ${ }^{58}$. According to the information in the chronicles, at this time, Huban-Haltaš I (689-681 BC) succeeded Umman-menanu to the throne of Elam without incident. ${ }^{59}$. There is no detailed information about Huban-Haltaš $\mathrm{I}$ in the chronicles. The most detailed information about him is that he died of a stroke. However, it is accepted that he established a stable relationship with Babylonia and Assyria during his eight-year reign. After the death of Huban-Haltaš I, Huban-Haltaš II (681-75 BC) ascended the throne of Elam. This period, when Huban-Haltaš II ascended the throne of the Neo-Elamite kingdom, the Assyrian state was in great turmoil ${ }^{60}$.

Sennacherib dealt with various problems in the western regions of Assyrian Empire for the rest of his life and was later killed as a result of a plot in which his sons were involved in $680 \mathrm{BC}$. His death is very likely to have resulted from the fact that he selected his younger son, Esarhaddon, as the heir to the Assyrian throne rather than his older sons who were already sitting on the Assyrian and Babylonian thrones. Despite some fights for the Assyrian throne following Sennacherib's death, Esarhaddon (680$669 \mathrm{BC}$ ) managed to defeat his two older brothers and became the Assyrian king, which made him the strongest king in the ancient Near East ${ }^{61}$.

The reign of Esarhaddon started in a period when the Neo-Assyrian state was politically volatile. Meanwhile, on the throne of Elam was Huban-haltaš II (681-675 $\mathrm{BC}$ ), who held control of Southern Babylonia ${ }^{62}$. It can be observed that the Elamite state is first mentioned during a military campaign against Sealand in the same period. According to Esarhaddon's annals about the campaign, the Babylonian problem was not still solved, and Neo-Elamites formed an alliance with Babylonians in order to weaken Assyrian hegemony in the region. In this respect, they attempted to enthrone Nabû-zêrkitti-līšir, who was Marduk-apla-iddina II's son and an official of Sealand, as the Babylonian king. However, after this political development was prevented by Esarhaddon's military campaign, Nabû-zēr-kitti-līšir fled towards Elam where he was captured and killed by the Neo-Elamites. The fact that the Neo-Elamites killed Nabûzēr-kitti-līšir whom they supported against Assyrians raises several questions. It is quite likely that they killed him because they needed to maintain a friendly attitude towards the Assyrian king and thus prevent a potential military campaign against Elam. After this incident, Na'id-Marduk of Bīt-Yakīn, who was Nabû-zēr-kitti-līšir's brother, was appointed as the governor of Sealand by Esarhaddon ${ }^{63}$. Although Na'id-Marduk was held captive by Elamites before he became a king, he ran away and took refuge in

\footnotetext{
${ }^{58}$ Brinkman 1972, p. 279; Brinkman 2008, p. 38; Cancik 2004, p. 102; Köroğlu 2013, p. 174; Yiğit 2020, p. 204; Ay Arçın, 2020, p. 279.

${ }^{59} \mathrm{ABC} 1$, iii 27.

${ }^{60}$ Waters 1997, pp. 60-61.

${ }^{61}$ Yalvaç 1963, pp. 47-54; Frame 2007, p. 66; Gökçek 2015, p. 186.

${ }^{62}$ Waters 2013, p. 484.

${ }^{63}$ RINAP 4, no. 1/ii, 50b-64; Porter 1993, p. 34; Waters 1997, pp. 61-62; Bauer 2013, p. 427; Topaloğlu and Uslu 2020: p. 293.
} 


\section{Okay PEKŞEN}

Assyria. Therefore, he was likely to be an important ally for Assyrians in the solution of the Babylonian problem. In order to prevent a possible alliance between the Assyrians and Babylonians, the Neo-Elamites decided to attack the Babylonian territory, which caused Na'id-Marduk to send a letter to Esarhaddon and ask for assistance. It can be easily understood from the letter that Esarhaddon did not fully trust in Na'id-Marduk. Nevertheless, the fact that a pro-Assyrian king from Bīt-Yakin was sitting on the Babylonian throne greatly reduced the Neo-Elamite influence on the region ${ }^{64}$. After having eliminated Neo-Elamite influence on Babylon, the Assyrian king also took same measures against Neo-Elamite attacks. One of the most striking examples of these measures is a treaty signed with Bēl-iqišsa, the king of Gambulu, in order to strengthen the city of Ša-pī-Bēl against potential Neo-Elamite attacks on the Gambulu border ${ }^{65}$. Meanwhile, the Neo-Elamites were planning to help Nabû-ušallim, Na'id-Marduk's pro-Elamite brother, sit on the Babylonian throne and thus regain their hegemony in the region. For this aim, they first lied to people about the death of Na'id-Marduk to facilitate the enthronement process. However, Babylonian officials did not believe in the false news about the death, which must have ruined Elamite plans for a certain time. It can be safely argued that $\mathrm{Na}$ 'id-Marduk died within a short time because a letter to the Assyrian king informed him about how Elamite troops had entered Babylon and declared Nabû-ušallim as the new king ${ }^{66}$. In addition, the Neo-Elamite king's attack on the city of Sippar and massacre of dozens there in $675 \mathrm{BC}$ clearly demonstrated that he aimed to reduce Esarhaddon's influence on the region ${ }^{67}$. Despite the Neo-Elamites' hostile attitudes towards Esarhaddon, he was not reported to have launched any military campaigns against Elam. Instead, the Assyrian king made certain attempts to solve his problems with Neo-Elamites through diplomatic channels. This can be attributed to Esarhaddon's intention to focus on a military campaign against Egypt rather than any other regions ${ }^{68}$. Meanwhile, the death of Huban-haltaš II, the Neo-Elamite king, and Urtaku's enthronement ${ }^{69}$ helped Esarhaddon to sign a treaty of friendship and nonaggression between two kings (c. $674 \mathrm{BC}$ ), which marked the beginning of a politically stable and peaceful era in the southern region ${ }^{70}$. There are two main reasons why Urtaku, the Neo-Elamite king, agreed to sign a treaty with Esarhaddon. Firstly, he aimed to prevent the Assyrian king from launching a military campaign against Elam. Secondly, as manifested by cuneiform letters which Neo-Assyrian and Neo-Elamite kings sent each other, Urtaku's sons were held captive by Esarhaddon ${ }^{71}$, which must have forced Urtaku to maintain a friendlier attitude towards Assyrians. Therefore, it is evident that although he was forced by internal and external communities to violate the treaty signed with the Assyrian king, Urtaku had to commit to it and adopt a peaceful

\footnotetext{
${ }^{64}$ Toptaş 2021, p. 115.

${ }^{65}$ Waters 1997, pp. 65-66; Waters 2013, p. 484.

${ }^{66}$ Frame 2007, pp. 81, 88-89.

${ }^{67}$ Waters 1997, p. 62.

${ }^{68}$ Toptaş 2021, p. 116.

${ }^{69}$ ABC 14, 16-18.

${ }^{70}$ Frame 2007, p. 88; Gökçek 2015, p. 199.

${ }^{71}$ SAA $16,1,1-8$.
} 
policy. Esarhaddon prism, which was found in Susa excavations and dates back to 673 $\mathrm{BC}$, can be considered as a significant evidence of Assyrian influence on Elam ${ }^{72}$.

Following the death of Esarhaddon, his younger son, Ashurbanipal, (668-626 BC) succeeded to the Assyrian throne, while his elder son, Šamaš-šuma-ukîn (667-647 BC) succeeded to the Babylonian throne. In fact, despite being the Babylonian king, Šamaš-šuma-ukin acted as a vassal king who took orders from his brother sitting on the Assyrian throne ${ }^{73}$. Esarhaddon appointed his elder son, i.e. Šamaš-šuma-ukîn, as the King Regent, which was undoubtedly a political move. However, he also needed to justify his decision on a religious basis, as the Babylonian governors had to be Babylonians authorized by Marduk, who was the God of Babylon. Therefore, during the consecration ceremony when Šamaš-šuma-ukîn became the King Regent, Esarhaddon introduced a new custom and offered Šamaš-šuma-ukîn as a gift to Marduk and Zarpanitu. Thus, from a cultural perspective, he turned his son ascending to the Babylonian throne into a Babylonian to receive religious support, strengthen Šamaššuma-ukîn's legitimacy and control over Babylonian territory and prevent any potential future riots ${ }^{74}$.

When Ashurbanipal became the king of the Assyrian Empire, which can be labelled as the superpower of ancient ages, the borders of his empire extended from Central Anatolia to the Persian Gulf and from Eastern Mediterranean coasts to the south of Lake $\operatorname{Van}^{75}$. As Ashurbanipal did not face any major problems after ascending to the throne apart from a few small-scale uprisings, he turned his face towards $\mathrm{Egypt}^{76}$. Peaceful relations with Neo-Elamites which started during the reign of Esarhaddon enabled Ashurbanipal to conduct military activities in the southern parts of his empire comfortably. Friendly diplomacy between Neo-Assyrians and Neo-Elamites continued during the early years of Ashurbanipal ${ }^{77}$. This reached such an extent that Ashurbanipal sent wheat to Elamites when they lost most of their crops due to a severe drought in Elam and also allowed starving Elamite peasants to settle in the Assyrian territory. However, Elamites did not give up their hegemonic intentions on Babylon and conducted anti-Assyrian activities in the city. Taking advantage of the Assyrian king's military campaign in Egypt, Neo-Elamites supported rebellions against the Assyrian Empire in Babylon. Thus, while facing problems in Anatolia, the Levant and Egypt, the Assyrian king also had to deal with various problems caused by Elamites. Meanwhile, Urtaku, the Neo-Elamite king, also encountered a rebellion in his own country when he was involved in anti-Assyrian activities. Urtaku and his sons were defeated and dethroned by a usurper, Teumman, who was depicted "in the shape of a demon"78 in

\footnotetext{
72 Toptaş 2021, p. 117.

${ }^{73}$ Brinkman 1972, p. 279; Johnston 1904, pp. 79-80.

${ }^{74}$ Zaia 2019, p. 251.

${ }^{75}$ Gökçek 2015, p. 202.

${ }^{76}$ Yiğit 2020, p. 209.

77 Waters 1997, p. 73.

${ }^{78}$ RINAP 5/1, no: 3 / vi, 68.
} 


\section{Okay PEKŞEN}

cuneiform texts and later became the new Elamite king ${ }^{79}$. However, he did not change Elamites' hostile attitude towards Assyrians, which resulted in an indispensable battle between Neo-Elamite and Neo-Assyrian armies when Assyrian troops proceeded towards Elam in $653 \mathrm{BC}^{80}$. The battle, which Ashurbanipal did not take part in, is called the Battle of Til Tuba (The Battle of Ulai River ${ }^{81}$. The war ended with a decisive victory for the Assyrian army, Teumman was beheaded and his head was taken to Ashurbanipal who was waiting in Nineveh. It is clearly stated in Ashurbanipal annals that Teumman's head was hung on the city gate as a warning for other enemies ${ }^{82}$, as can be read in the following lines:

"(As for) the decapitated head of Teumman, I displayed (it) opposite the

Citadel Gate of Niniveh as a spectacle in order to show the people the

might of (the god) Aššur and the goddess Ištar, my lords - the decapitated

head of Teumman, the king of the land Elam." 83

In addition, the scene was also illustrated in various reliefs around the palace in Niniveh. For instance, a relief depicts the Assyrian king and queen who celebrate their victory and raise their glasses, while Teumman's decapitated head hangs on a tree behind them ${ }^{84}$.

After Teumman was killed by Assyrians, Ashurbanipal managed to control Elam and demolished the central authority of the Elamite state by dividing Elamite territory into two separate states: Susiyana and Anzan. He appointed Ummanigaš II and Tammaritu, who was Ummanigaš II's brother, to manage both states, respectively, making it easier for him to intervene in the internal affairs of Elamites ${ }^{85}$.

Ashurbanipal did not encounter any problems in Babylon, as his brother, Šamaššuma-ukîn was sitting on the Babylonian throne for a long time ${ }^{86}$. However, towards the end of the reign of Šamaš-šuma-ukîn (652-648 BC), he was supported by Neo-Elamite king Indabibi (649?-648? BC), to pave the way for a great rebellion against the Assyrian king, Ashurbanipal, who was also his brother, and forbade his access to the holy cities of Babylonia ${ }^{87}$. Ashurbanipal repressed the rebellion caused by Šamaš-šuma-ukîn very savagely, killed him and appointed Kandalanu (647-627 BC) to manage Babylon. After the fall of Babylon and the plunder of the land of Elam by Ashurbanipal, Huban-haltaš III (648?-645? BC) ascended the throne of Elam. Meanwhile, Ashurbanipal also proceeded towards the central parts of Elam and destroyed the city of Susa and nearby

\footnotetext{
${ }^{79}$ Gerardi 1987, p. 133.

${ }^{80}$ Gökçek 2015, p. 209; Memiş 2020, p. 270; Topaloğlu and Uslu 2020, p. 297.

${ }^{81}$ Waters 2013, p. 481.

${ }^{82}$ Starr 1985, p. 60; Gerardi, 1987, p. 138; Potts 2004; p. 277; Toptaş 2018, p. 188; Topaloğlu and Uslu 2020, p. 297.

${ }^{83}$ RINAP 5/1, no: 3 / vi, 57-60.

${ }^{84}$ Reade 1983, p. 68; Köroğlu 2013, p. 179.

${ }^{85}$ Waters 1997, p. 92; Waters 2002, p. 79; Gökçek 2015, p. 210-211; Memiş 2020, p. 271.

${ }^{86}$ Köroğlu 2013, p. 179.

${ }^{87}$ Cancik 2004, p. 118; Akyüz and Toptaş 2020, p. 229.
} 
$(647 ? \mathrm{BC})^{88}$. The Assyrian king's activities in the Elamite territory are narrated in cuneiform texts as follows:

"I gathered together the colossi, the guardians of the temple, all that there were, I removed the fierce wild-oxen which adorned their gates. The sanctuaries of Elam I destroyed totally (lit., to non-existence). Its gods (and) goddesses I scattered (lit., counted) to the wind(s). Their secret groves, into which no stranger (ever) penetrates, whose borders he never (over) steps,- - into these my soldiers entered, saw their mysteries, and set them on fire. The sepulchers of their earlier and later kings, who did not fear Assur and Ishtar, my lords, (and who) had plagued the kings, my fathers, I destroyed, I devastated, I exposed to the sun. Their bones (members) I carried off to Assyria. I laid restlessness upon their shades. I deprived them of food offerings and libations of water.

For a (distance) of a month of twenty-five days' journey I devastated the provinces of Elam. Salt and sihlu (some prickly plant) I scattered over them." 89

Another reason why the Assyrian king proceeded towards the Elamite territory and destroyed it was the fact that Nabû-bēl-šumati, who was the Chaldean governor of Sealand, supported his brother's rebellion and took refuge in Elam ${ }^{90}$. A letter sent by the Assyrian king to the Elamite elders contains the following passage:

"[Why] have we been treated like this?" [I swe]ar by [Aššur and my gods] that it is because of [Nabû-bēl-šumati and the of]fenders who are with him that you have been treated like this. First of all, why would I myself persecute your country? If it were some sort of trading post of precious stone(s), I would say "Let me seize it and add it to my land" or "Let me take horses and mules from its midst and add them to my forces." or I would say "It is a place of silver and gold, let me impose tribute upon them" or "There are things worthy of kingship in its midst." But there is nothing of the sort in it. Why, then, would I myself persecute your country? Now then, I am writing to you: Send to me Nabû-bēl-šumati and those with him, and then I myself will send to you your gods and make peace. However, if you delay or do not comply, by Aššur and my gods, I swear that under the aegis of the gods I will make your future become your past." $" 91$

Since the political structure in Elam during the period in question has not been revealed yet, it is not possible to ascertain who the Elamite elders whom Ashurbanipal addressed were, what their organizations were for or which authorities they possessed.

After these developments, Huban-haltaš III, who received the news that Ashurbanipal was marching on Madaktu, the royal city of Elam, left the city and fled to

\footnotetext{
88 Johnston 1904, p. 80; Waters 1997, p. 116; Kuhrt 2013, pp. 159-160; Oates 2015, p. 128.

${ }^{89}$ ARAB II, 810-811.

${ }^{90}$ Waters 1997, p. 102; Crouch 2009, pp. 151-152.

${ }^{91}$ Waters 2002, p. 82.
} 


\section{Okay PEKŞEN}

the mountains. Turning this situation into an opportunity, Umbahabua (Elamite Hubanhabua), who was rival of Huban-haltaš III, ascends to the throne of Elam. However, no cuneiform text mentions him as a king. The annals describe him as a mihirtu ${ }^{92}$ of Huban-haltas ${ }^{93}$. Following these events, the Elamite territory remained under the Assyrian hegemony until $640 \mathrm{BC}$ when it was captured by the Medes ${ }^{94}$.

\section{Conclusions}

The imperial power of Neo-Assyrian state threatened other states in the Ancient Near East, as the Assyrian economy relied heavily on spoils of war obtained from military campaigns. It can be observed that Assyrians kings usually launched military campaigns against regions which were remote from their royal cities. One of the most important routes in these military campaigns was Babylon due to its strategic location in terms of controlling the Persian Gulf and its high economic potential. In addition, it was also necessary to control various rebellious groups in the same region. These groups sometimes managed to capture Babylon and declare independence when the Assyrian king started a military campaign towards a different region, all of which contributed to Assyrian interests negatively. Therefore, Assyrian kings usually launched military campaigns to solve the above-mentioned problems in Babylon and appointed their loyal officials or members of Assyrian dynasty to the Babylonian throne. However, it was not uncommon that these kings encouraged rebellions against the Assyrian state or were overthrown by rebels. Witnessing the impracticality of appointing officials to the Babylonian throne in terms of controlling the region, Assyrian kings often found it necessary to intervene militarily in the region.

Assyrian kings often encountered serious loyalty issues when they appointed a new local governor to the Babylonian throne as a vassal king to maintain their control over the region. Therefore, as a solution to this problem, they decided to appoint young princes from Assyrian dynasty, which aimed at eliminating all potential conflicts in Babylon and thus enabling Assyrian kings to launch more active military campaigns in various regions such as Anatolia, Levant and Egypt. However, it can be suggested that this strategy was not also a complete remedy for the loyalty problem attributed to the Elamite provocation in Babylon and non-Babylonian origin of Assyrian princes as well as religious differences between two people. For instance, while Assyrians worshipped the God Aššur, Marduk was the chief god in Babylon. Considering that the cult of chief god bore utmost importance in Mesopotamian societies, a conflict between local Babylonian people and Assyrian governors was almost inevitable. As a result, Assyrian kings tried to find various solutions to this conflict and end Babylonian problem. One of the most striking solutions was to benefit from the vast influence of religious elements on the Babylonian society. The fact that Esarhaddon offered his son, Šamaš-šuma-ukîn, as a gift to Marduk, who was the chief god of Babylon and his wife, Zarpanitu, was an unprecedented move towards eliminating religious differences between local people and

\footnotetext{
92 mihirtu means "counterpart" or "equivalent". see CAD, M/II, p. 51.

${ }^{93}$ Waters 1997, p. 119.

${ }^{94}$ Brinkman, 1972, p. 279; Gökçek 2015, p. 211; Yıldırım 2020, p. 322.
} 
governors, which also facilitated the Assyrian control over Babylon. In other words, it can be argued that when necessary, Assyrian kings did not refrain from making concessions in their religious beliefs. However, such an extraordinary strategy was not also a long-term solution to this problem, as there was another major power who aimed to take Babylon under their control.

The Neo-Elamite state was the first and foremost major power that aimed to hinder the Assyrian hegemony in Babylon, as their economic interests in the Persian Gulf and Babylon were threatened by the Assyrian existence. In addition, a possible Assyrian hegemony in Babylon was likely to result in the neighboring borders between Assyria and Elam, which was then a big threat to the Elamites' independence. This was because Assyrians probably aimed to capture the Neo-Elamite state after establishing their hegemony over Babylon. Therefore, Neo-Elamite kings were usually forced to create a buffer zone between the Neo-Assyrian and Neo-Elamite states. This can also be attributed to the fact that Elamite kings usually preferred a weaker Babylon controlled by them as their neighbors rather than facing a powerful Assyrian state. To this aim, they provided political and financial support to rebels in Babylon to weaken and eliminate Assyrian authority in the region.

It can be also stated that in addition to using military methods, Assyrian kings sometimes resorted to diplomatic relations to solve problems with the Neo-Elamites. In this respect, they signed various treaties with Neo-Elamite kings and helped the NeoElamite state financially. However, such a friendly attitude towards Elam did not suffice to solve the above-mentioned problems, as the Neo-Elamites attacked their territory when Neo-Assyrian kings launched military campaigns against remote locations and did not end their activities in Babylon. Therefore, the last option for Assyrians to solve the Babylonian and Elamite problem was to launch military campaigns against Elam, which helped them capture the Neo-Elamite state and divide it into two different states governed by Assyrian officials. However, despite solving the Elamite problem, a greater problem emerged for Assyrians when the Medes found the opportunity to control the region on account of the lack of a central Elamite authority and exert their hegemony over the Elamite territory. It can be thus concluded that Assyrians' Elam policies also paved the way for the emergence of the Medes who played a vital role in the fall of the Assyrian Empire. 


\section{Okay PEKŞEN}

\section{BIBLIOGRAPHY}

$\mathrm{ABC}$

A. Kirk Grayson, Assyrian and Babylonian Chronicles, Eisenbrauns, 2000, Winona Lake, Indiana.

Akyüz and Toptaş 2020 Faruk Akyüz - Koray Toptaş, "Yeni Asur İmparatorluğu: Savaşın Kralları", in: Eski Mezopotamya'nın Siyasi Tarihi, L.G. Gökçek - E. Yıldırım - O. Pekşen (Eds.), Değişim Yayınları, İstanbul, pp. 195-244.

Álvarez-Mon 2012 Javier Álvarez-Mon, "Elam: Iran's First Empire", in: A Companion to the Archaeology of the Ancient Near East, D.T. Potts (Ed.), Blackwell Publishing Ltd., New Jersey, pp. 740757.

ARAB II Daniel D. Luckenbill, Ancient Records of Assyria and Babylonia-II, The University of Chicago Press, 1927, Chicago.

Arnold 2004

Bill T. Arnold, Who were the Babylonians?, Society of Biblical Literature, Atlanta.

Ay Arçın 2020 Şeyma Ay Arçın, "Orta Babil Krallığı (Kassitler) ve Babil'de İkinci İsin Hanedanlığı -Yeni Babil Krallığı”, in: Eski Mezopotamya'nın Siyasi Tarihi, L.G. Gökçek - E. Yıldırım - O. Pekşen (Eds.), Değişim Yayınları, İstanbul, pp. 263-290.

Bauer 2013

Susan Wise Bauer, Antik Dünya Illk Kayttlardan Roma'nın Dağılmasina Kadar, Trans.: M. Moralı, Alfa Yayınları, İstanbul.

Brinkman 1965 J. A. Brinkman, "Elamite Military Aid to Merodach-Baladan", Journal of Near Eastern Studies, 24/3, Erich F. Schmidt Memorial Issue, Part One, pp. 161-166.

Brinkman 1972 J. A. Brinkman, "Foreign Relations of Babylonia from 1600 to 625 B.C.: The Documentary Evidence", American Journal of Archaeology, 76, pp. 271-281.

Brinkman 1973 J. A. Brinkman, "Sennacherib's Babylonian Problem: An Interpretation", Journal of Cuneiform Studies, 25/2, pp. 89-95.

Brinkman 2008 J. A. Brinkman, "Babylonia in the shadow of Assyria (747-626

B.C.)", in: The Cambridge Ancient History, III/2, J. Bordman et al. (Eds.), Cambridge University Press, Cambridge, pp. 1-70.

CAD

The Assyrian Dictionary of the Oriental Institute of the University of Chicago, Miguel Civil - Ignace J. Gelb - A. Leo Oppenheim - Erica Reiner (eds.), Chicago, 2004.

Cancik-Kirschbaum 2004 Eva Cancik-Kirschbaum, Asurlular (Tarih, Toplum, Kültür), Trans.: A. Yarbaş, İlya Yayınları, İzmir.

Crouch 2009 Carly L. Crouch, War and Ethics in the Ancient Near East: Military Violence in Light of Cosmology and History, Band 407, Walter De Gruyter, Berlin. 
Elayi 2017

Eph'al 1974

Frame 2007

Galter 2007

Gerardi 1987

Gökçek 2015

Hansman 1978

Hawkins 2008

Johnston 1904

King 1910

Kitab-1 Mukaddes

Köroğlu 2013

Kuhrt 2013

Medvedskaya 1999

Memiş 2020

Oates 2015

Olmstead 1922
Josette Elayi, Sargon II, King of Assyria, SBL Press, Atlanta.

I. Eph'al, "“Arabs" in Babylonia in the 8th Century B.C.", Journal of the American Oriental Society, 94/1, pp. 108-115. Grant Frame, Babylonia 689-627 B.C. A Political History, Nederlands Instituut voor het Nabije Oosten, Leiden.

Hannes D. Galter, "Looking Down The Tigris The Interrelations Between Assyria and Babylonia", in: The Babylonian World, G. Leick (Ed.), Routledge, New York and London, pp. 527-540.

Pamela D. Gerardi, Assurbanipal's Elamite Campaigns: A Literary And Political Study, PhD Thesis, University of Pennsylvania.

L. Gürkan Gökçek, Asurlular, Bilgin Kültür Sanat Yayınları, Ankara.

J.F. Hansman, "The Mesopotamian Delta in The First Millennium, BC", The Geographical Journal, 144/1, pp. 4961.

J. D. Hawkins, "The Neo-Hittite States in Syria and Anatolia", in: The Cambridge Ancient History, III/1, J. Bordman et al. (Eds.), Cambridge University Press, Cambridge, pp. 372-441.

Christopher Johnston, "Šamaš-šum-ukîn the Eldest Son of Esarhaddon", Journal of the American Oriental Society, 25, pp. 79-83.

Leonard W. King, A History of Sumer and Akkad, Frederick A. Stokes Company Publishers, New York.

Kitab-ı Mukaddes (Kutsal Kitap), Yeni Yaşam Yayınları, 2010, İstanbul.

Kemalettin Köroğlu, Eski Mezopotamya Tarihi Başlangıcından Perslere Kadar, İletişim Yayınları, İstanbul.

Amelie Kuhrt, Eski Çă̆'da Yakındoğu (M.Ö. 3000-330), II, Trans.: D. Şendil, Türkiye İş Bankası Kültür Yayınları, İstanbul.

I.N. Medvedskaya, "Media and Its Neighbours I: The Localization of Ellipi”, Iranica Antiqua, XXXIV, pp. 53-70.

Ekrem Memiş, Eskiçă̆da Mezopotamya (En Eski Çă̆lardan Asur Imparatorluğu'nun Yıkılışına Kadar), Ekin Yayınevi, Bursa.

Joan Oates, Babil, Trans.: F. Çizmeli, Arkadaş Yayınları, Ankara.

Albert T. Olmstead, "The Fall and Rise of Babylon", The American Journal of Semitic Languages and Literatures, XXXVIII/2, pp. 73-96. 
Parpola 1972

Porter 1993

Potts 1997

Potts 2004

Reade 1983

RIMA 3

RINAP 1

RINAP 2

RINAP 3/1

RINAP 3/2

RINAP 4

RINAP 5/1

SAA 16

Starr 1985

Tadmor 1958
Simo Parpola, "A Letter from Šamaš-šumu-ukīn to Esarhaddon", Iraq, 34/1, pp. 21-34.

Barbara N. Porter, Images, Power, and Politics Figurative Aspects of Esarhaddon's Babylonian Policy, American Philosophical Society, Philadelphia.

Daniel T. Potts, Mesopotamian Civilization-The Material Foundations, The Athlone Press, London.

Daniel T. Potts, The Archaeology of Elam-Formation and Transformation of an Ancient Iranian State, Cambridge University Press, Cambridge.

Julian E. Reade, Assyrian Sculpture, Harvard University Press, Cambridge.

A. Kirk Grayson, Assyrian Rulers of the Early First Millenium BC II (858-745 BC), University of Toronto Press, 2002, Toronto.

Hayim Tadmor - Shigeo Yamada, The Royal Intextions of Tiglath-pileser III (744-727 BC) and Shalmaneser V (726-722 $B C$ ), Kings of Assyria (The Royal Intextions of the NeoAssyrian Period 1), Eisenbrauns, 2011, Winona Lake.

Grant Frame, The Royal Intextions of Sargon II, King of Assyria (721-705 BC) (The Royal Intextions of the NeoAssyrian Period 2), Eisenbrauns, 2021, Winona Lake.

A. Kirk Grayson and Jamie Novotny, The Royal Intextions of Sennacherib, King of Assyria (704-681 BC), Part 1, (The Royal Intextions of the Neo-Assyrian Period 3/1), Eisenbrauns, 2012, Winona Lake.

A. Kirk Grayson and Jamie Novotny, The Royal Intextions of Sennacherib, King of Assyria (704-681 BC), Part 2, (The Royal Intextions of the Neo-Assyrian Period 3/2), Eisenbrauns, 2014, Winona Lake.

Erle Leichty, The Royal Intextions of Asarhaddon, King of Assyria (680-669 BC). (The Royal Intextions of the NeoAssyrian Period 4), Eisenbrauns, 2011, Winona Lake.

Jamie Novotny and Joshua Jeffers, The Royal Intextions of Ashurbanipal (668-631 BC), Assur-etal-ilani (630-627 BC), and Sin-sarra-iskun (626-612 BC), Kings of Assyria, Part 1, (The Royal Intextions of the Neo-Assyrian Period 5/1) Eisenbrauns, 2018, Winona Lake.

State Archives of Assyria, XVI, Simo Parpola (Ed.), Helsinki University Press, 2002, Helsinki.

Ivan Starr, "Historical Omens Concerning Ashurbanipal's War Against Elam”, Archiv für Orientforschung, 32. Bd., pp. 60-67. Hayim Tadmor, "The Campaigns of Sargon II of Assur: A 
Chronological-Historical Study", Journal of Cuneiform Studies, 12/3, pp. 77-100.

Topaloğlu and Uslu 2020 Yasin Topaloğlu - Serhat Uslu, “Asur Devleti’nin Y1kılışı ve Medler”, in: Eski Mezopotamya'nın Siyasi Tarihi, L.G. Gökçek - E. Yıldırım - O. Pekşen (Eds.), Değişim Yayınları, İstanbul, pp. 291-320.

Toptaş 2018

Toptaş 2021

Waters 1997

Waters 2002

Waters 2011

Waters 2013

Yalvaç 1963

Y1ldırım 2017

Y1ldirım 2020

Yiğit 2020

Zaia 2019
Koray Toptaş, "Yeni Asur Emperyalizminin Bir Sonucu Olarak İsyanlar", Archivum Anatolicum (ArAn), 12/2, pp. 179-200.

Koray Toptaş, Asarhaddon Asur Kralı, Babil Yöneticisi, Misır Fatihi, Berikan Yayınları, Ankara.

Matthew W. Waters, A Survey of Neo-Elamite History, PhD Thesis, University of Pennsylvania.

Matthew W. Waters, "A Letter from Ashurbanipal to the Elders of Elam (BM 132980)", Journal of Cuneiform Studies, Vol. 54, pp. 79-86.

Matthew W. Waters, "Parsumaš, Anšan, and Cyrus", in: Elam and Persia, J. Álvarez-Mon - M. B. Garrison (Eds.), Eisenbrauns, Winona Lake, Indiana.

Matthew W. Waters, "Elam, Assyria, and Babylonia in the Early First Millennium BC", in: Oxford Handbook of Ancient Iran, D. T. Potts (ed.), Oxford University Press, pp. 478-492.

Kadriye Yalvaç, "Sanherib'in Ölümü ve Asarhaddon", AÜDTCFD, 21/1.2, pp. 47-54.

Ercüment Yıldırım, Eskiçăg Mezopotamya'sında Liderler Krallar Kahramanlar, Arkeoloji ve Sanat Yayınları, İstanbul. Ercüment Yıldırım, "Mezopotamya'da Pers Hakimiyeti", in: Eski Mezopotamya'nın Siyasi Tarihi, L.G. Gökçek - E. Yıldırım - O. Pekşen (Eds.), Değişim Yayınları, İstanbul, pp. 321-342.

Turgut Yiğit, Eski Mezopotamya Tarihi (Tarihöncesinden Pers Istilasına Kadar), Bilgin Kültür Sanat Yayınları, Ankara.

Shana Zaia, "Going Native: Šamaš-Šuma-Ukīn, Assyrian King of Babylon”, IRAQ, 81, pp. 247-268. 